\title{
Why, What and How? Editing Early Modern Scientific Letters in the 21st Century
}

Hubert Steinke

Armstrong, Alan W. (ed.), "Forget not Mee \& My Garden ...". Selected letters 1725-1768 of Peter Collinson (Philadelphia 2002)

Bots, Hans/Rob Visser (éds), La Correspondance, 1785-1787, de Petrus Camper (1722-1789) et son fils Adriaan-Gilles Camper (1759-1820) (Amsterdam 2002)

Chambers, Neil (ed.), The Letters of Sir Joseph Banks: a selection, 1768-1820 (London 2000)

Hunter, William et al. (eds), The correspondence of Robert Boyle, 6 vols (London 2001)

Lawrence, Christopher/Fiona A. Macdonald (eds), Sambrook Court. The letters of J. C. Lettsom at the Medical Society of London (London 2003)

Keywords: medical correspondence; scientific correspondence; editions; electronic editions

Letters of great physicians and scientists have always been cherished. They have been and still are by many considered as genuine expressions which allow us to get a true picture of the life and thought of a remarkable figure. Modern historiography does not totally reject this view but it calls for caution because scientists do not necessarily reveal their true thoughts and actions in letters and because letter-writing itself is defined by social conventions. Nevertheless - or for that very reason - modern historians of science and medicine have taken increased interest in epistolary exchanges. Several studies have shown that the critical use and interpretation of letters allow us to follow "science in the making" und to observe what went on "behind the scenes" . They demonstrate that the collection and spread of information, the exchange of ideas, the scientific institutions and the whole organisation of science heavily depends on and is shaped by letters ${ }^{2}$. In fact, the entire

1 Mahony et al. 1997; Geison 1995.

2 Hall 2002; Spary 2000.

Dr. Dr. Hubert Steinke, Medizinhistorisches Institut, Bühlstrasse 26, CH-3009 Bern (hubert. steinke@mhi.unibe.ch). 
community of learned men is linked through letters, which reveal certain codes of conduct underlying and maintaining the attitudes and actions of the scholars ${ }^{3}$. Physicians, too, considered themselves as learned gentlemen and as part of the Republic of Letters ${ }^{4}$. And their medical practice depended significantly on correspondence as they discussed medical matters with their distant colleagues and were consulted by letters 5 . Furthermore, letters give not only evidence of the activities of physicians but - as this theme issue shows - of medical culture and health and sickness in general.

Modern historical research, therefore, is not only interested in letters of great men and women but in all letters pertaining to the realms of science and medicine. These include certainly scholarly but also many diplomatic, administrative, military, business and family letters linked in one way or another with the world of learning and research. The main focus, however, is on letters exchanged between members of the Republic of Letters, and if we are interested in the history of the natural and medical sciences, it is mainly these that we have to study. Although several millions of such letters are preserved, their number is not infinite. It is, in fact, rather small if we take into account that during World War I four million letters made their way from or to the front in France every day ${ }^{6}$. Nonetheless, we have to ponder carefully which letters are worth to be published. The Commission for German Studies has calculated in 1975 that a single book page of a correspondence edition costs up to DM 10,000 $(=€ 5,000)$ if all the various expenditures are counted ${ }^{7}$. This is presumably too high an estimate which applies only to critical editions of the highest standard and complexity, like those of Leibniz or Newton. Even so editing is a time-consuming and expensive business which needs some reflection. I will first look at some typical recent editions of medical and scientific letters, then ask for criteria of selection and finally address the issue of electronic editing.

\section{Recent editions}

Alan Armstrong has edited a selection of the letters of Peter Collinson (1694-1768), a trader of quality fabrics, botanist, indefatigable collector of plants and active member of the Royal Society. Collinson's correspondence must have been quite large as not less than 750 of his letters written to 75 per-

3 Goldgar 1995.

4 Brockliss 2002; Broman 1996.

5 Schnalke 1997; Brockliss 1994.

6 Hanna 2004.

7 Frühwald et al. 1977. 
sons survive although no single large collection exists. Armstrong's edition contains 192 of Collinson's letters to 27 persons and is intended "to provide a convenient picture of his interests and influences" (xxvii). The letters concern above all botany and the exchange of plants and illustrate that botanical studies depended probably more than any other branch of science on international contacts and correspondence. Communicators like Collinson, even if not important authors themselves, played an eminent role in the Republic of Letters not least because they usually considered themselves as servants to the ideal of the advancement of knowledge. Hence they were less concerned with their own reputation than more eminent scientists and thus ready to establish unspectacular but useful contacts which the latter neglected. Collinson's particular merit was his correspondence with America from where he introduced many plants to the Old World. He was an interesting, easy and entertaining letter-writer, and it is therefore a pleasure to peruse Armstrong's lavishly illustrated book. From the viewpoint of the professional historian, however, the edition is unsatisfactory. We have no idea on what grounds the letters were selected. Are these the "highlights" of Collinson's correspondence, and if so, from what point of view? It seems that Armstrong chose mainly letters written to well-known figures, but we do not know. A list of all the 750 surviving letters would have helped here. The historian may, of course, use the edition to quote from single letters, but he is not put in a position to furnish a reliable description of Collinson's correspondence in general. The next editor to come - there certainly will be one - has to face an awkward situation, too. Should he edit another selection of letters, all the remaining unedited letters, or should he provide a full edition of all the surviving letters? Judging from the development of the historical research, he will do the last - and thus render Armstrong's book obsolete.

Hans Bots and Rob Visser present a selection of letters too, but their selection is easily defined and explained. They have edited the correspondence between Petrus Camper (1722-1789) and his son Adriaan Gilles Camper (1759-1820) from 1785 to 1787. The 122 letters cover the period of Adriaan's stay in Paris where he was to complete his scientific education, to collect objects of natural history, to promote his father's unpublished works on comparative anatomy and, more specifically, to win Buffon's support and collaboration for a work on the natural history of the whales. The correspondence therefore is above all an important source for the history of vertebrate anatomy and natural history in the late 18 th century. On a more general level it offers a vivid picture of both the father's and the son's daily duties and shows how much scientific activity is based on and shaped by personal contacts and interests, background information and means of 
communication (an index of persons would have helped to illustrate this). The editors point out that the 168 remaining unedited letters, mostly exchanged during the son's travels in Germany, Switzerland and Italy (17841788), deal with quite different subjects. Those of the father contain mainly paternal advice and reflections on the political situation, whereas those of the son have the features of a travel journal with descriptions of tourist attractions and people he met. The decision to omit this larger part of the correspondence is understandable from the viewpoint of somebody primarily interested in the history of biology. Anyone dealing with the structure and ideals of the Republic of Letters at large, however, will regret it, as education, father-son relationships, political discussion and travels are important elements of its culture. And to know how these - as well as other social, political and ideological factors - are connected with the world of learning and science, is one of the main questions modern historians of the Enlightenment are concerned with.

Christopher Lawrence and Fiona Macdonald have edited yet another type of selected correspondence, i.e. all the letters to and from John Coakley Lettsom (1744-1815) preserved at the Medical Society of London. Lettsom was one of the leading London physicians of his time, a founder of charitable and medical societies and a prolific letter-writer. He has written and received several thousand letters of which only a fraction has survived. The Medical Society holds approximately 220 letters and thus presumably the largest collection, but many more do exist (e.g. 91 at the Wellcome Institute). As the editors point out, the letters edited form a very miscellaneous group. There is rarely ever a topic which may be followed through several letters. As such, the book gives insight into a variety of medical and social issues. The dissatisfaction of the reader, however, remains as he does not quite understand what this book is meant to be. It serves neither as a well-chosen partial edition of Lettsom's surviving letters nor as a coherent source collection for social or medical historians. Lawrence and Macdonald, who have been invited by the Medical Society to edit the letters, probably felt equally uneasy. The title of the book - Sambrook Court, the place where Lettsom lived, wrote and received his letters - looks like a compromise solution as if the editors could not find any other link that would hold the book together. They have done their best to impose some order upon the collection and provided a good index, but could not change the fact that they are offering an accidental selection of a late 18th-/early 19th-century correspondence.

Michael Hunter and his co-editors of Robert Boyle's (1627-1691) correspondence have been in quite another situation. First of all, Boyle is one of the leading figures of late 17th-century intellectual life and one of the great 
heroes of science. Secondly, his letters survived to a considerable extent, although certainly many are lost. And thirdly, his correspondence is not huge but still of a significant size (roughly 1,000 letters) to form a rich source for the study of Boyle and his world. There is no doubt that the full edition of such a corpus is highly welcome and helpful even if two thirds of the letters have already been published in various works in the past 250 years. The letters are particularly important because Boyle is a paradigmatic figure for science studies focussing on the relation between scientific research, philosophy and the Republic of Letters, and because letters often shed more or a different light on these relations than printed works do.

Still another case is that of Sir Joseph Banks (1743-1820), the famous explorer, naturalist, patron of science and politician. His correspondence was truly gigantic and global. Of an estimated 50,000 letters some 20,000 (14,000 from and 6,000 written to 3,000 correspondents) have survived in various archives around the world. The Banks Research Project at the Natural History Museum in London catalogues all the letters and presently prepares the publication of Banks' scientific correspondence (approximately 3,000 letters). In the meantime, Neil Chambers has edited a selection of 137 of Banks' letters "to offer the general public a preview" (xii), "a representative glimpse" (xix) of the whole. The book is, therefore, mainly a promotional product, albeit a good and justified one. Large research projects need public attention and funding, and Banks and his correspondence are certainly worthy of this attention. The selected edition delivers a vivid picture of Banks' colourful world and presumably will achieve its purpose. As to the larger project, one may wonder how a clear set of 'scientific letters' can be separated from others which presumably are not. Chambers has - besides "science" defined 19 further thematic groups and labelled them, e.g. "societies and institutions", "Royal Society", "library and herbarium", "agriculture and horticulture", "Indo-Pacific" or "social and domestic". Readers of early modern letters are accustomed to find all these various themes in one single letter, and certainly the edition of Banks' 'scientific correspondence' will not contain all the letters discussing scientific matters. Furthermore, the idea of separating letters of scientific content from those dealing with scientific societies does certainly not reflect our modern understanding of how science works. Nevertheless, one comprehends the editor's reluctance to embark on a single complete (chronological or alphabetical) edition of all 20,000 letters. When Chambers' edition appears (presumably in 2006), we will at least be provided with a remarkable core set of scientific letters.

8 Chambers 1999. 


\section{Corpora of letters}

The editions so far discussed have applied various criteria of selection which reflect different interests and traditions. By defining the principles of selection, the editors put the letters into a certain context. Even the edition of a complete correspondence of a single individual furnishes such a context as it directs the focus on one central figure. Letters do not, as Chambers hopes, "speak for themselves" . We have moved beyond the antiquarian notion that every letter is simply a source showing "how it was". Every editor becomes - or should become - aware of his or her own power when annotating letters for edition. A specialist of Newton's mathematics will furnish quite another annotation of Sir Isaac's correspondence than a historian primarily interested in the network of the Scientific Revolution - and thus deliver another picture of what the letters are about. Even more so do the selection and grouping of letters shape our perception of a certain period or aspect of history. The fact that we publish the separate complete correspondences of Newton, Boyle, Leibniz, etc. and not an 'archive of correspondence of the Scientific Revolution' greatly affects our view of how science worked in these times ${ }^{10}$. What and how we edit is not only defined by the actual interests of historiography, it equally shapes the development of historical research itself. Most historians are not editors and more prone to use editions than to search for manuscript letters. A colleague explained to me why she studied Freud instead of other psychiatrists: "Well, you know, everything is so nicely edited, with all the registers you need, etc." We should bear that in mind when embarking on an editorial project.

The first and foremost question an editor has to ask her- or himself is therefore: what is an appropriate corpus to be edited? This means looking beyond the material one might have at hand and thinking globally or, if concerned with early modern medicine, science and the Republic of Letters, at least European. If one plans to edit a specific set of letters, one should know what other letters there are in order to decide whether the intended choice is a reasonable and useful one. An (incomplete) list of the large correspondence networks may give a first idea of what has survived (table 1 ). There are many other, somewhat smaller and still significant correspondences like those of Mersenne, Newton or Malpighi which might complete the list. And there are, of course, many more networks of members from the Republic of Letters from Erasmus to Voltaire, who were not directly concerned with the natural

9 Chambers 2000, xxi.

10 Several large collections of 17th-century science are presented in Hunter 1998. 


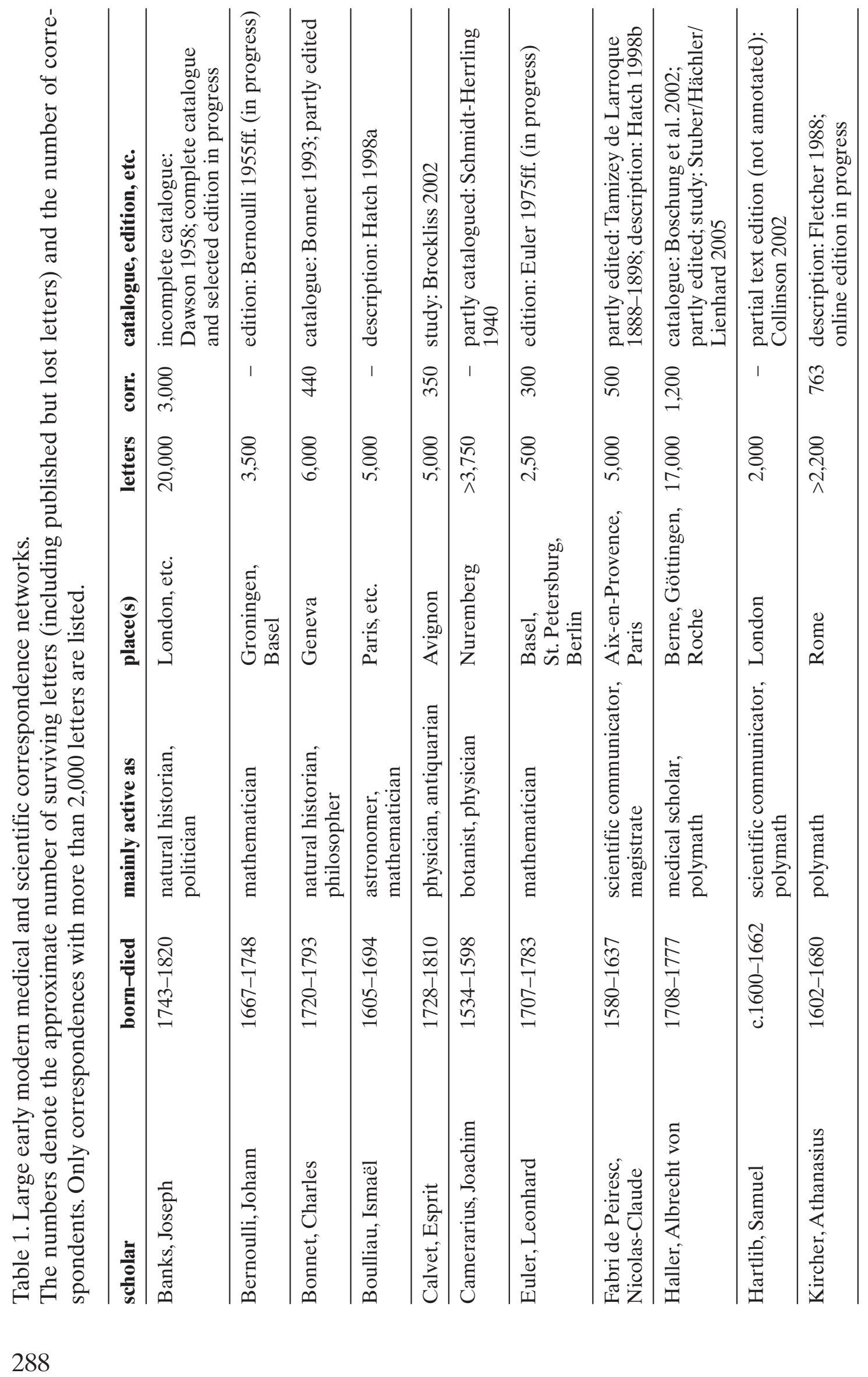




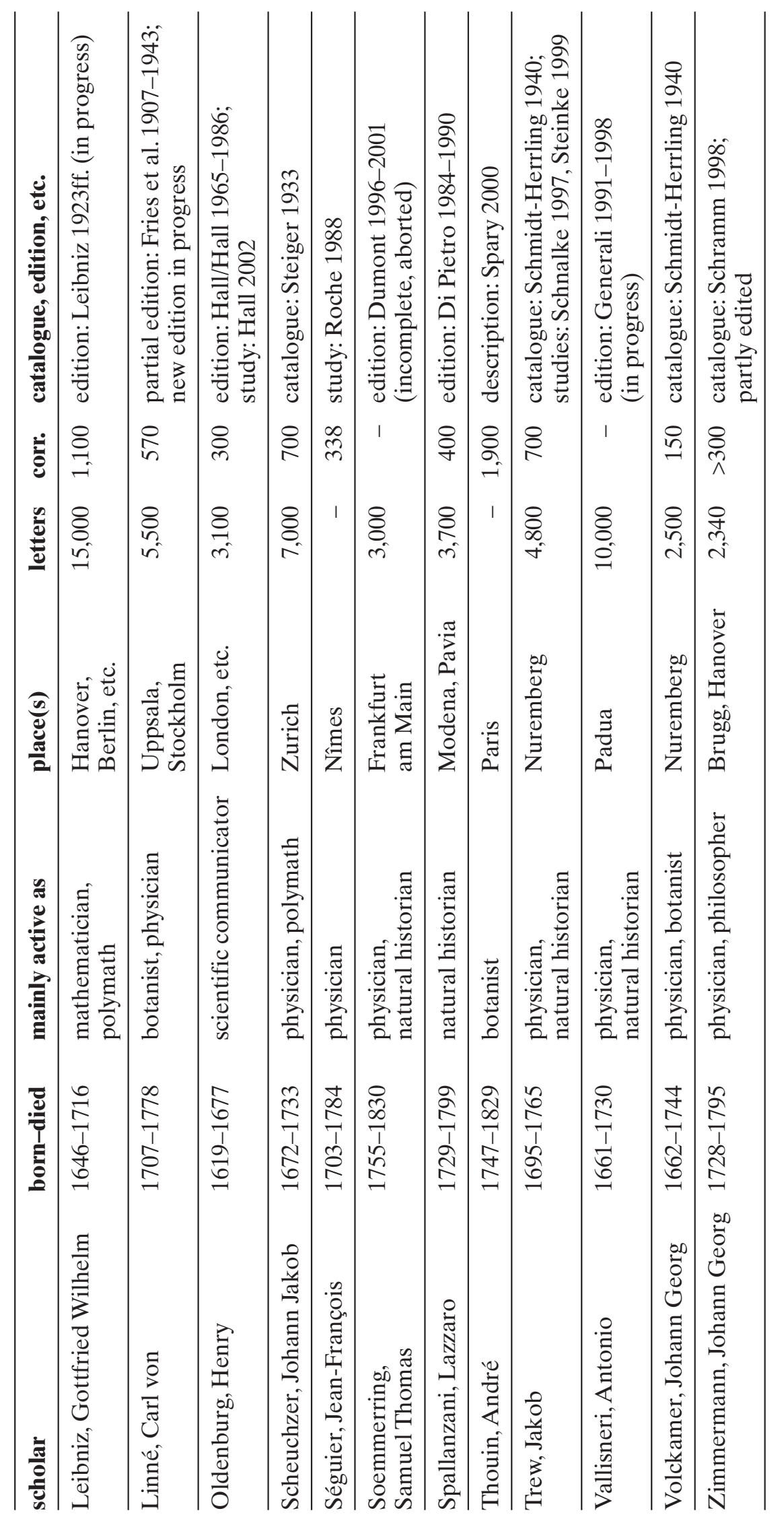


and medical sciences but who had various contacts with physicians and natural philosophers. But even such an expanded list shows only the tip of the iceberg, and a tip mainly focussed on 'big' figures. Though not necessarily so. Our list contains, for instance, two relatively unknown physicians with a large network, Calvet and Trew. Both their correspondences have been studied and they shed some light on the world of physicians and the Republic of Letters ${ }^{11}$. Calvet and Trew are figures that might be compared with Lettsom; they both wrote thousands of letters and enjoyed some reputation, but are worth to be studied as representatives of a certain type of physician or as members of the learned world rather than as singular personalities on their own. From such a perspective it has to be doubted that the selection of Lettsom's letters at the Medical Society was a good choice. There must be many equal if not more revealing collections of letters to illustrate various aspects of 18th-century English medicine and culture. Only studies based on more complete epistolary samples allow us to draw some general conclusions. It would therefore have been a good approach first to search for all the remaining letters from and to Lettsom and then to ask whether the whole or a part of it should be edited. This is what the - admittedly much larger - Banks project has done.

Searching for manuscripts is, however, a laborious task. Everybody aiming at a complete edition has to contact hundreds of archives in order to achieve a reasonably comprehensive catalogue. In the last few years, some databases have somewhat facilitated this search. Kalliope, for instance - the continuously growing central catalogue of German autographs -, records several hundred thousands of letters (dating for the greater part after 1800), and in a similar manner the $A 2 A$ interface gives evidence of letters through its access to archive catalogues in England ${ }^{12}$. These resources are helpful but replace the traditional search only to a limited degree. Historians of early modern culture are far away from the enviable situation of those of twentieth-century physics, who have at their disposal a catalogue of 700,000 letters of physicists, scattered in 2,000 archival collections around the world ${ }^{13}$. The equivalent to this unique repertory would be a universal inventory of the correspondence of the Republic of Letters, as dreamed of by Jean-Daniel Candaux ${ }^{14}$. Such an inventory would record all the letters written from or to the scholars of early modern Europe, thus including the full surviving correspondence of smaller figures but not of those outside

11 Brockliss 2002; Steinke 1999; Schnalke 1997.

12 http://kalliope.staatsbibliothek-berlin.de; http://www.a2a.org.uk.

13 Wheaton 1993.

14 Candaux 2003. 
the learned world. This would not only greatly help those who are searching specific letters but - what is much more important - it would allow us to gain a much broader view of the sciences and the Republic of Letters, beyond the few giants of learning. And it would assist us in our decision which correspondence or letters should be studied and - eventually - edited.

In the long run, early modern studies would profit from a shift from the meticulous edition of some few correspondences to a gradual creation of such or similar inventories, which could contain additional biographical information on the authors and, in the end, even the edited letters themselves. As long as nobody is embarking on such a Herculean task - and it does not look like this is going to happen soon - large correspondence networks are, however, well-suited corpora to work on. They may be edited in a scholarly manner, i.e. either as the total set of surviving letters or in parts as single complete correspondences between two persons. Like that, later editors may add other correspondences without creating a confusion of edited and non-edited letters. Large networks may, however, also be studied without being edited ${ }^{15}$. And they may be the starting point for the search for many minor figures and smaller correspondences worth to be examined in their turn.

\section{Electronic editing}

Each larger editorial project nowadays faces one main question: paper and/or electronic edition? The question is, of course, a complex one and can here only partially be dealt with. As a general rule, electronic editions should at least achieve the minimal editorial levels of printed ones. If not so, their value is greatly reduced. The electronic CD edition of the Hartlib Papers is a good case for that ${ }^{16}$. It offers a complete transcript and the images of 25,000 manuscript pages and thus a unique resource to 17 th-century science. The edition contains, however, neither an index nor annotations. The knowledge of persons, books and events mentioned - which the transcribers must have acquired in order to be sure of their reading - is lost and has to be gained anew by every reader. To undertake the great task of full transcription and present only the naked text thus appears as a rather uneconomical decision. If a project regards even minimal annotation as too time consuming, it is probably wiser to refrain from transcriptions and to consider a much simpler and less expensive option. This is what the State Library of New South Wales

15 Cf. Stuber/Hächler/Lienhard 2005; Brockliss 2002.

16 Collinson 2002; cf. also Hunter 2003. 
in Sydney has done with its Banks' Papers. It provides online access to 10,000 pages of letters and other manuscripts, which are not transcribed but comprehensively indexed and easily searchable ${ }^{17}$. In addition, the whole access is free of charge and contrasts positively with the strategy the editors of the Hartlib Papers endorsed. They sell their CDs at a price beyond the range of average University libraries and thus have done a disservice to their project: only few copies seem to have been sold (in Switzerland, for instance, there is not a single copy available). Libraries are ready to pay considerable sums for critical editions that remain the standard reference works for decades, but not for an unselected collection of material that in the near future might be superseded by a more thorough edition.

Making an entire archival collection available appears as an fascinating idea, the result is, however, an image of the archive and only partially of the person the collection should reveal. A serious scholarly edition should not be limited by the boundaries of a single archive but aim at the publication of a comprehensive and coherent corpus of manuscripts. If this corpus reaches a certain size, the laborious creation of a database enabling an electronic edition may be worthwhile. There seem to be three main sorts of products such a database may endeavour. The first is the edition of the complete correspondence of one person. At the moment, no such correspondence has yet been published on a large scale. Those to be issued in the near future, i.e. those of Boyle, Voltaire and Rousseau, are electronic versions of the earlier printed editions. They offer improved search facilities but not a fundamentally new approach ${ }^{18}$. The editions of Voltaire and Rousseau are, however, only the first step in the larger project Electronic Enlightenment of the Voltaire Foundation, which aims at a single database recording the letters of various 18th-century authors, thus intending to "lay bare the networks which underlie the growth of Enlightenment thought" 19 . The editors of Pierre Bayle's correspondence move in a similar direction although they began from a different starting point. They have created a database which serves not only as the source for the ongoing critical edition of the letters but also as the tool for further investigations into the European network of correspondence of the 17 th century ${ }^{20}$. The manifold links between the persons, books and subjects recorded furnishes new insight into the structures of the Republic

17 http://www.sl.nsw.gov.au/banks.

18 An even simpler but still very useful electronic edition is the publication of a PDF file of the printed book. The editors of Leibniz's works have adopted the very laudable policy of offering their new volumes free of charge at http://www.leibniz-edition.de/Baende.

$19 \mathrm{http}: / / \mathrm{www} . e-e n l i g h t e n m e n t . i n f o$.

20 McKenna/Leroux 2003; cf. also Lochard/Taurisson 2002. 
of Letters. And the database may be expanded continuously through the inclusion of other correspondences. This idea of a combined edition of several correspondences represents the second type of electronic projects, but it has not yet been taken up by historians of science and medicine. It seems to make sense especially for the network of the 'Scientific Revolution', as many of its letters are published in several editions (e.g. of Boyle, Oldenburg, Huygens) and thus illustrate to what extent the single correspondences are interwoven into a whole. The ultimate goal would, however, be Candaux's dream of one single database covering all the correspondences of the Republic of Letters. The third type of electronic publication aims at a reconstruction of the world of one person, based on his complete correspondence as well as other documents like diaries, laboratory protocols, library catalogues, unpublished and published works and many more sources giving evidence of his private and scientific life and work. Such a project makes only sense in the case of a large collection of material, and it requires a great deal of work. The Panopticon Lavoisier, for instance, designed on the model of the Pinakes database, links a large amount of documents but still only a small number of transcriptions ${ }^{21}$. And the Haller Project records even more objects but even less transcriptions $^{22}$. The advantage of such digital enterprises is, however, that they are capable of continuous development. Although no scientist or physician has yet been thoroughly explored by means of a database, this is a promising path to be followed.

Our short survey makes clear that we are still at the very beginning of electronic editing. Not a single electronic edition of a large correspondence network is fully available today. However, given the potentials of databases there is no doubt that this will change soon. On the one hand, databases facilitate the production of traditional scholarly editions, especially in large teamwork projects like that of the Edizione nazionale delle opere di Antonio Vallisneri to be published online as well as on $\operatorname{paper}^{23}$. On the other hand, they enable us to gain new insights into the network and the whole world of early modern scholars, which paper editions cannot provide. This neither renders the traditional quality standards of editing nor the paper editions themselves obsolete. But it puts the old question why, what and how to edit, into a new light.

21 http://www.pinakes.org; cf. Scotti 2003.

22 Steinke 2003.

23 Generali 2003. 


\section{Bibliography}

Armstrong, Alan W. (ed.), "Forget not Mee \& My Garden ...". Selected letters 1725-1768 of Peter Collinson (Philadelphia 2002)

Der Briefwechsel von Johann Bernoulli (Basel 1955ff.)

Catalogue de la correspondance de Charles Bonnet conservée à la Bibliothèque de Genève (Genève 1993)

Boschung, Urs et al. (Hrsg.), Repertorium zu Albrecht von Hallers Korrespondenz 1724-1777, 2 Bde. (Basel 2002)

Bots, Hans/Rob Visser (éds), La Correspondance, 1785-1787, de Petrus Camper (1722-1789) et son fils Adriaan-Gilles Camper (1759-1820) (Amsterdam 2002)

Brockliss, Laurence W. B., "Consultation by Letter in Early Eighteenth-Century Paris: the medical practice of Etienne-François Geoffroy", in: Ann La Berge/Mordechai Feingold (eds), French Medical Culture in the Nineteenth Century (Amsterdam 1994) 79-119

- Calvet's Web. Enlightenment and the Republic of Letters in Eighteenth-Century France (Oxford 2002)

Broman, Thomas, The transformation of German academic medicine, 1750-1820 (Cambridge 1996)

Candaux, Jean-Daniel, «Pour un inventaire universel des correspondances de la République des Lettres: une utopie en douze points», in: Monti (2003) 175-179

Chambers, Neil (ed.), "Letters from the President: the correspondence of Sir Joseph Banks", Notes and Records of the Royal Society 53/1 (1999) 27-57

- The Letters of Sir Joseph Banks: a selection, 1768-1820 (London 2000)

Collinson, Patrick et al. (eds), The Hartlib Papers. A complete text and image database of the papers of Samuel Hartlib (c. 1600-1662), 2 CDs (Sheffield 2002)

Dawson, Warren R. (ed.), The Banks Letters. A calendar of the manuscript correspondence of Sir Joseph Banks preserved in the British Museum, the British Museum of Natural History and other collections in Great Britain (London 1958)

Di Pietro, Pericle (ed.), Edizione nazionale delle opere di Lazzaro Spallanzani. Parte I: Carteggi, 12 vols (Modena 1984-1990)

Dumont, Franz (Hrsg.), Samuel Thomas von Soemmerring, Briefwechsel, 4 Bde. (Stuttgart 1996-2001)

Leonhardi Euleri commercium epistolicum (Basel 1975ff.)

Fletcher, John (Hrsg.), Athanasius Kircher und seine Beziehungen zum gelehrten Europa seiner Zeit (Wiesbaden 1988)

Fries, Th. M. et al. (eds.), Bref och skrifvelser af och till Carl von Linné, 10 vols (Stockholm, etc. 1907-1943)

Frühwald, Wolfgang et al. (Hrsg.), Probleme der Brief-Edition (Boppard 1977)

Geison, Gerald L., The Private Science of Louis Pasteur (Princeton 1995)

Generali, Dario (ed.), Antonio Vallisneri. Epistolario 1679-1713, 2 voll. (Milano 1991-1998)

- «L'Edizione Nazionale delle Opere di Antonio Vallisneri: stato e prospettive dei lavori», in: Monti (2003) 33-53

Goldgar, Ann, Impolite Learning. Conduct and community in the Republic of Letters, 1680-1750 (New Haven/London 1995)

Hall, Marie Boas, Henry Oldenburg: shaping the Royal Society (Oxford 2002)

Hall, Rupert A./Marie Boas Hall (eds), The Correspondence of Henry Oldenburg, 13 vols (Madison/London 1965-1986)

Hanna, Martha, "A Republic of Letters: the Epistolary Tradition in France during World War I", American Historical Review 104 (2004) 1338-1361

Hatch, Robert, "Between Erudition \& Science: The Archive \& Correspondence Network of Ismaël Boulliau", in: Michael Hunter (ed.), Archives of the Scientific Revolution. The formation and exchange of ideas in seventeenth-century Europe (Rochester 1998a) 49-71

- "Peiresc as Correspondent. The Republic of Letters and the geography of ideas", in: Brian P. Dolan (ed.), Science Unbound: geography, space, discipline (Umeå 1998b) 19-58

Hunter, Michael (ed.), Archives of the Scientific Revolution. The formation and exchange of ideas in seventeenth-century Europe (Rochester 1998) 
- et al. (eds), The correspondence of Robert Boyle, 6 vols (London 2001)

- "Whither editing?" [review essay], Studies in History and Philosophy of Science 34/4 (2003) $805-820$

Lawrence, Christopher/Fiona A. Macdonald (eds), Sambrook Court. The letters of J. C. Lettsom at the Medical Society of London (London 2003)

Leibniz, Gottfried Wilhelm, Sämtliche Schriften und Briefe, hrsg. von der Berlin-Brandenburgischen Akademie der Wissenschaften (Berlin 1923ff.)

Lochard, Eric-Olivier/Dominique Taurisson, «Correspondances, réseaux, édition électronique», in: Pierre-Yves Beaurepaire (éd.), La plume et la toile. Pouvoirs et réseaux de correspondance dans l'Europe des Lumières (Arras 2002) 171-192

Mahony, Patrick et al. (eds), Behind the Scenes: Freud in correspondence (Oslo 1997)

McKenna, Antony/Annie Leroux, «L'édition électronique de la correspondance de Pierre Bayle», in: Monti (2003) 181-189

Monti, Maria Teresa (ed.), Antonio Vallisneri. L'edizione del testo scientifico d'età moderna (Firenze 2003)

Roche, Daniel, «Correspondance et voyage au XVIII ${ }^{\mathrm{e}}$ siècle: le réseau des sociabilités d'un académicien provincial», in: Daniel Roche, Les Républicains des Lettres. Gens de culture et Lumières au XVIII' siècle (Paris 1988) 263-286

Schmidt-Herrling, Eleonore, Die Briefsammlung des Nürnberger Arztes Christoph Jacob Trew (1695-1769) in der Universitätsbibliothek Erlangen (Wiesbaden 1940)

Schnalke, Thomas, «Medizin im Brief. Der städtische Arzt des 18. Jahrhunderts im Spiegel seiner Korrespondenz», Sudhoffs Archiv, Beihefte 37 (Stuttgart 1997)

Schramm, Hans-Peter, «Der Zimmermann-Nachlaß in der Niedersächsischen Landesbibliothek Hannover», in: Hans-Peter Schramm (Hrsg.), Johann Georg Zimmermann, königlich großbritannischer Leibarzt (1728-1795), Wolfenbütteler Forschungen 82 (Wiesbaden 1998) 221-267

Scotti, Andrea, «Nouve metodologie e tecnologie nella storia documentaria della scienza: l'esempio di Pinakes», in: Monti (2003) 205-224

Spary, Emma, Utopia's Garden. French natural history from Old Regime to Revolution (Chicago 2000)

Steiger, Rudolf, Verzeichnis des wissenschaftlichen Nachlasses von Johann Jakob Scheuchzer (1672-1733) (Zürich 1933)

Steinke, Hubert (Hrsg.), Der nützliche Brief. Albrecht von Hallers Korrespondenz mit Christoph Jakob Trew 1733-1763 (Basel 1999)

- "Archive Databases as Advanced Research Tools: the Haller Project", in: Monti (2003) 191204

Stuber, Martin/Stefan Hächler/Luc Lienhard (Hrsg.), Hallers Netz. Ein europäischer Gelehrtenbriefwechsel zur Zeit der Aufklärung (Basel 2005, in Vorbereitung)

Tamizey de Larroque, Philippe (éd.), Lettres de Peiresc, 7 vols (Paris 1888-1898)

Wheaton, Bruce R. (ed.), Inventory of Sources for the History of Twentieth Century Physics. Report and microfiche index to 700,000 letters, 61 Microfiches (Stuttgart 1993) 